JURNAL SEHAT MASADA VOLUME XV XVMOR $1 \quad$ JOnuari $2021 \quad$ ISSN : 1979-2344

\title{
HUBUNGAN PENGETAHUAN DENGAN KECEMASAN IBU HAMIL PRIMIGRAVIDATERHADAP BERHUBUNGAN SEKS SELAMA KEHAMILAN DI WILAYAHKERJA PUSKESMAS SEI LANGKAI KOTA BATAM
}

\author{
Susanti \\ Program Studi D-III Kebidanan Fakultas Kedokteran Universitas Batam \\ susanti.1187@gmail.com
}

\begin{abstract}
ABSTRAK
Penelitian yang dilakukan oleh Badan Koordinasi Keluarga Berencana Nasional (BKKBN) disebutkan bahwa pengetahuan dasar kesehatan reproduksi relatif terbatas sebesar 57,89\% responden tidak mengetahui pengertian seksualitas. Sikap responden terhadap promosi kesehatan seksualitas berdasarkan mitos dalam masyarakat memberikan indikasi yang relatif baik, namun nuansa keraguan juga relatif terasa. Informasi mengenai seksualitas hanya 58,33\% didapat melalui tenaga kesehatan, dan $31,67 \%$ didapat melalui sumber lain. Pengetahuan sebagai alat jasminan yang sangat penting untuk terbentuknya tindakan seseorang dari pengalaman dan penelitian terbukti bahwa perilaku didasarkan atas pengetahuan akan lebih langgeng dibandingkan dengan tanpa didasari pengetahuan. Salah satu faktor yang menyebabkan terjadinya seksualitas terganggu adalah pengetahuan dan kecemasan.

Tujuan penelitian ini untuk mengetahui hubungan.Pengetahuan ibu hamil primigravida trimester I terhadap berhubungan seks selama kehamilan di Wilayah kerja Puskesmas Sei Langkai Kota Batam.

Penelitian ini bersifat Cross Sectional, tempat penelitian Wilayah kerja Puskesmas Sei Langkai Kota Batam, populasi penelitian adalah ibu hamil yang datang melakukan ANC dengan teknik pengambilan sample Accidental Sampling, jumlah sample 48 responden. Instrument yang digunakan untuk variable independen da variable dependen menggunakan kuisioner yang telah di uji validitas yang digunakan yaitu analisa chi-square.

Hasil penelitian yang dilakukan dari 48 responden mempunyai pengetahuan yang baik dan melakukan stimulasi dengan baik yaitu 30 responen $(62,5 \%)$, p-value $0.003<0.05$.
\end{abstract}

Kata kunci :Pengetahuan, kecemasan ibu hamil trimester I, Seks

\section{ABSTRACT}

In a research conducted by Coordination Board of National Family Planning (BKKBN) mentions that the basic knowledge of reproduction health is limited as by 57,89\% respondents do not know the definition of sexuality. The respondents' attitude towards sexuality health promotion based on the myth in the community gives relatively good indication, however the doubt nuance is also relatively felt. The information about sexuality is only 58,33\% obtained through health staffs, 31,6\% obtained from other sources.

The knowledge as an extremely important guarantee tool for the formation someone's action from the experience and research proven that the behavior is based on the knowledge then it will last compared to the one which is not based on the knowledge. One of factors which cause the occurance of sexuality disorder is knowledge and anxiety. Knowledge is the basic of someone's attitude to be formed. Anxiety is the feeling of fear on unreasonable worry about something which is not fun related to the soul and open psychological condition.

The purpose of this research is to find out the correlation between the knowledge of primigravides pregnant women trimester I on sex relationship during pregnancy at work area of Sei Langkai Community Health Center (Puskesmas) Batam City.

The research population was accidental, the pregnant women who came to do ANC could become the sample through Accidental Sampling, total samples were 48 respondents. The instrument used for 
independent variable and dependent variable was questionnaire which had been validated by using chi-square analysis.

The bivariate result namely of 48 respondents owning good knowledge and did good stimulation is 30 respondents $(62,5 \%)$. The bivariate result obtains the correlation between the pregnant women's knowledge about sex ralationship during pregnancy and the result of chi-square p-value $0.003<0.05$.

Therefore, it can be concluded that there is correlation between the knowledge of primigravide pregnant women trimester I owards sex relationship during the pregnancy at work area of Sei Langkai Community Health Center (Puskesmas) Batam City

\section{Keywords: Knowledge, Pregnant women trimester I, Sex}

\section{PENDAhuluan}

World Health Organization (WHO) menyatakan, seksualitas yang sehat menggambarkan hubungan dan integrasi yang positif antara kondisi fisik, emosional, intelektual dan seksual seorang individu dalam berbagai cara yang dapat memperkaya dan meningkatkan personalitas, komunikasi, dan cinta kasih seksual dirinya dalam menjalinhubungan dengan orang lain. Seorang pakar keperawatan menyatakan, Virginia Henderson menyatakan bahwa manusia memiliki 14 kebutuhan dasar hidup yang wajib dipenuhi untuk menjaga kelangsungan hidupnya. Seksualitas adalah salah satu komponen penting kebutuhan dasar manusia dari 14 kebutuhan dasar manusia tersebut.

Kebutuhan seksual manusia diantaranya manusia membutuhkan kelembutan, hubungan kedekatan atau intimai dengan orang terdekat, tampil menarik didepan publik, mencintai dan dicintai, dan bereproduksi. Kebutuhan psikologis ibu jika tidak terpenuhi terutama kebutuhan seks saat hamil dapat mengakibatkan tekanan pada psikologis ibu dan dapat berdampak pada pertumbuhan dan perkembangan janin yang dikandungnya, kelahiran premature, dan keguguran(Widiasmoko, 2009 dalam Permatasari,2015).

Sesuai dengan persyaratan yang di anjur olehWorld Health Organization (WHO) bahwa hubungan seksual meskipun dilakukan oleh pasangan suami istri yang sudah menikah tetap harus memenuhi beberapa ketentuan. Ketentuan tersebut yang utama yaitu aman, sehat menyenangkan dan tanpa paksaan(Wiknjosastro,2005)

Upaya pelayanan kesehatan yang dilakukan untuk dapat mengubah pandangan masyarakat tentang aktivitas seksual selama kehamilan adalah dengan memberikan pelayanan pada ibu hamil secara cermat dan tepat dengan rencana strategi nasional Making Pregnancy Safer dengan misi menurunkan kesakitan dan kematian ibu dan bayi baru lahir sebagai prioritas program pembangunan nasional (Depkes RI, 2010).

Beberapa situasi yang menyarankan untuk menghentikan hubungan seks yaitu jika terdapat tanda infeksi dengan pengeluaran cairan disertai rasa nyeri atau panas, terjadi perdarahan saat berhubungan seks, terdapat pengeluaran cairan (air) yang mendadak, 
JURNAL SEHAT MASADA VOLUME XV

pernah mengalami keguguran, terjadi plasenta previa, kehamilan kembar. (Manuaba, 2008)

Hubungan seksual merupakan aspek penting yang perlu diperhatikan bagi pasangan suami istri dalam kehidupan rumah tangga karena bagaimanapun hubungan seksual yang baik merupakan bentuk komunikasi yang paling penting diantara pasangan suami istri. Dalam melakukan hubungan seksual ada beberapa faktor yang mempengaruhi pengetahuan tentang hubungan seksual yaitu: Tingkat pendidikan, Informasi, Budaya dan Pengalaman (Notoatmodjo, 2003).

Trimester pertama adalah saat yang spesial karna istri menyadari akan kehamilanya, akan tetapi perubahan seks dapat terjadi karena perubahan-perubahan yang terjadi secara fisik dan mental, khususnya pada istri pasangan umum.

Pengalaman yang tidak menyenangkan ini pada akhirnya dapat menimbulkan kekecewaan, yang dapat terjadi disfungsi seksual yaitu terjadi keengganan dan menolak untuk melakukan hubungan seksual, bahkan tidak mungkin melakukan hubungan seksual. Hal tersebut berpotensi mengganggu keharmonisan rumah tangga yaitu semantara pasangan merasa kecewa, jengkel, marah, melakukan hubungan seksual dengan orang lain sampai mengancam cerai dan menikah lagi (Prawirohardjo, 2005).

Dalam sebuah penelitian yang dilakukan oleh Badan Koordinasi Keluarga Berencana Nasional (BKKBN) disebutkan bahwa pengetahuan dasar kesehatan reproduksi relatif terbatas sebagaimana oleh $57,89 \%$ responden tidak mengetahui pengertian seksualitas. Sikap responden terhadap promosi kesehatan seksualitas berdasarkan mitos dalam masyarakat memberikan indikasi yang relatif baik, namun nuansa keraguan juga relatif terasa. Informasi mengenai seksualitas hanya $58,33 \%$ di dapat melalui tenaga kesehatan $31,67 \%$ didapat melalui sumber lain (BKKBN, 2005).

Menurut Profil Dinas Kesehatan Kota Batam tahun 2019.Data Ibu Hamil Terbanyak dengan Cakupan Pelayanan Kesehatan menurut Kecamatan dan Puskesmas yaitu di Kecamatan Sagulung, dengan Data Ibu Hamil tercatat sebesar 3.910 Ibu Hamil di Wilayah Kerja Puskesmas Sei Langkai Kota Batam.

Berdasarkan uraian latar belakang diatas, peneliti tertarik untuk mengetahui lebih jauh bagaimana "Hubungan Pengetahuan Dengan Kecemasan Ibu hamil Primigravida Trimester I terhadap Berhubungan Seks Selama Kehamilan" di Puskesmas Sel Langkai Kota Batam

\section{METODE}

Jenis penelitian yang digunakan adalah survei analitik.Survei analitik adalah survei yang diarahkan untuk menjelaskan suatu keadaan situasi. Didalam penelitian ini peneliti menggunakan pendekatan (jenis), yakni survey analitik cross sectional. Populasi penelitian sebanyak 42orang ibu hamil primigravida yang melakukankunjungan ANC 
JURNAL SEHAT MASADA VOLUME XV

di Wilayah KerjaPuskesmasSei Langkai Kota

Batam. Pengambilan sample dalam penelitian ini dilakukan dengan menggunakan metode Accidental Sempling pada ibu hamil primigravida trimester I yang memeriksakan kehamilannya di Wilayah KerjaPuskesmas Sei Langkai Kota Batam. Instrument yang digunakan dalam penelitian ini dengan menggunakan kuisioner sehingga mendapatkan data berupa data tanggapan atau responden sampel penelitian. Dalam pengambilan data penelitian, peneliti menggunakan kuisioner pertanyaan tentang pengetahuan. Pada kuesioner pengetahuan pada ibu hamil primigravida trimester I, yaitu dengan mencentang salah satu jawaban "Benar" atau "Salah". Untuk setiap jawaban kuesioner sikap dengan jawaban pertanyaan dengan cara mencrontreng kolom TP ( Tidak Merasa Cemas), KD (Kadang-Kadang), SR (Sering), SL (Selalu) (Machfoedz, 2008).

\section{HASIL DAN PEMBAHASAN}

a. Hasil

1) Pengetahuan Ibu Hamil Terhadap Berhubungan Seks
Tabel 1 Distribusi Frekuensi Pengetahuan Ibu hamil Primigravida Trimester I terhadap Berhubungan Seks Selama Kehamilandi Wilayah Kerja Puskesmas Sei Langkai Kota Batam

\begin{tabular}{lll}
\hline Pengetahuan & Frekuensi & Presentase \\
\hline Baik & 18 & $37,5 \%$ \\
\hline Kurang & 30 & $62,5 \%$ \\
\hline Jumlah & 48 & $100 \%$ \\
\hline
\end{tabular}

Hasil penelitian dari 48 responden diperoleh sebanyak 30 orang $(62,5 \%)$ yang berpengetahuan kurang, dan 18 orang $(37,5 \%)$ yang berpengetahuan yang berpengetahuan baik tentang berhubungan seks.

2) Kecemasan dalam berhubungan seks Selama Kehamilan

Tabel 2 Distribusi Frekuensi Kecemasan Ibu hamil Primigravida Trimester I terhadap Berhubungan Seks Selama Kehamilandi Wilayah kerja Puskesmas Sei Langkai Kota Batam

\begin{tabular}{llll}
\hline Variabel & Kategori & N & Persentasi \\
\cline { 1 - 4 } Kecemasan & Tidak pernah & 13 & 27,1 \\
\hline & $\begin{array}{c}\text { Kadang- } \\
\text { kadang }\end{array}$ & 13 & 27,1 \\
\hline & Sering & 12 & 25,0 \\
\hline Total & Selalu & 10 & 20,8 \\
\hline
\end{tabular}

Hasil penelitian dari 48 responden diperoleh sebanyak 13 orang $(27.1 \%)$ yang tidak merasa cemas, sebanyak 13 orang $(27.1 \%)$ yang kadang-kadang merasa cemas,sebanyak 12 orang $(25.0 \%)$ yang sering cemas dan sebanyak 10 orang (20.8) yang selalu.

Tabel 3 Hubungan Pengetahuan Dengan Kecemasan Ibu hamil Primigravida Trimester I terhadap Berhubungan Seks

\begin{tabular}{ccccccc}
\hline \multicolumn{7}{c}{ Kecemasan } \\
Penegtahuan & Tidak ada & Kecemasan & Kecemasana & Kecemasan & Total & $\rho$-value \\
\hline
\end{tabular}




\begin{tabular}{ccccccc}
\hline & cemas & Ringan & sedang & berat & & \\
\cline { 1 - 5 } Kurang & 3 & 8 & 10 & 9 & 35 & \multirow{2}{*}{$\mathbf{0 , 0 3}$} \\
\cline { 1 - 6 } Baik & 10 & 5 & 2 & 1 & 13 & \\
\cline { 1 - 6 } Total & 13 & 13 & 12 & 10 & 48 & \\
\hline
\end{tabular}

Berdasarkan dari tabel 3 dapat dilihat hasil analisa Hubungan Pengetahuan dengan Kecemasan Ibu Hamil Primigravida langkaikota Batam tahun 2020 dari uji Chisquare didapatkan $p$ value 0.03 lebih kecil dari 0,05 berarti Ho ditolak maka dapat disimpulkan bahwa ada Hubungan Pengetahuan Dengan Kecemasan Ibu Hamil Primigravida Trimester I Terhadap Berhubungan Seks Selama Kehamilan diwilayah kerja puskesmas Sei Langkai kota Batam

\section{b. Pembahasan}

Pengetahuan informasi tentang seks dapat diperoleh darimana saja, dari berbagai media massa dan media sosial yang berperan penting dalam memberi informasi pada masyarakat. Baiknya pengetahuan mereka dikarenakan mereka tidak sekedar tahu saja tetapi bisa memahami dan menganalisa pengetahuan yang mereka miliki.pengetahuan seseorang tergantung dari sumber informasi, pengalaman dan orang lain.

Penelitian ini sejalan dengan penelitian yang dilakukan oleh Nurymayasari di Wilayah Kerja Puskesmas Kesamben Kabupaten Jombang dimana terdapat 3 responden atau 7,9\% tidak mengalami kecemasan dan 35 responden atau 92,1\% mengalami kecemasan. Penelitian ini juga sejalan dengan penelitian Astuti (2010) dan Sulistyorin (2007) yang berjudul Pengaruh Peran Suami terhadap
Tingkat Kecemasan Ibu Hamil bahwa dari 80 responden sebanyak $53,75 \%$ mengalami kecemasan.

Sejalan dengan teori Wawan dan Dewi (2010) bahwa tingkat pengetahuan seseorang itu dipengaruhi beberapa faktor diantanya umur, pendidikan, pekerjaan, lingkungan dan budaya. Jadi kemungkinan karena karakteristik responden tersebut akan mempengaruhi tingkat pengetahuan ibu hamil tentang perkembangan janin sehingga mayoritas pengetahuannya adalah cukup seperti mengetahui perkembangan janin mulai dari terbentuk-bentuknya organ sampai berfungsinya sistem organ janin dalam kandungan.

Dari hasil penelitian Kecemasan pada Ibu hamil Primigravida Trimester I Terhadap Berhubungan Seks yaitu 18 responden 37,5\% dari 48 responden. Namun terdapat responden yang berpengetahuan kurang tetapi dalam dalam berhubungan seksual tidak cemas, dikarenakan ibu mendapatkan informasi yang baik tentang berhubungan seks elama kehamilan.

Menurut Stuart (2008), respon cemas seseorang tergantung pada kematangan pribadi, pemahaman dalam menghadapi tantangan, harga diri, dan mekanisme pertahanan diri yang digunakan untuk mengatasi kecemasannya antara lain dengan menekan konflik dan tak mau memikirkan hal yang kurang menyenangkan dirinya. Penelitian 
ini sejalan dengan penelitian yang dilakukan oleh Nurymayasari di Wilayah Kerja Puskesmas Kesamben Kabupaten Jombang dimana terdapat 3 responden atau 7,9\% tidak mengalami kecemasan dan 35 responden atau 92,1\% mengalami kecemasan. Penelitian ini juga sejalan dengan penelitian Astuti (2010) dan Sulistyorin (2007) yang berjudul Pengaruh Peran Suami terhadap Tingkat Kecemasan Ibu Hamil bahwa dari 80 responden sebanyak $53,75 \%$ mengalami kecemasan.

Menurut peneliti banyaknya ibu hamil yang mengalami kecemasan karena responden yang peneliti teliti itu adalah ibu primigravida dimana ibu mendapat informasi yang terbatas di awal kehamilannya dan belum punya banyak pengalaman serta timbul kecemasan dalam melakukan hubungan seksual selama hamil.Ibu juga mempercayai mito-mitos yang beredar seperti kalau hamil satu sampai tiga bulan itu tidak diperbolehkan melakukan hubungan seksual nanti bisa keguguran.Ibu yang tidak mengalami kecemasan saat hamil, dikarenakan ibu mempunyai pengetahuan tinggi tentang kehamilannya, ibu juga sering menggali informasi seputar kehamilannya, dan ibu memang pribadi yang tidak mudah cemas atau bisa mengontrol rasa khawatir atau cemasnya dengan caranya sendiri.

$\begin{array}{ccr}\text { Berdasarkan } & \text { hasil penelitian } \\ \text { terhadapHubungan } & \text { Pengetahuan } & \text { dengan }\end{array}$ Kecemasan Ibu Hamil Primigravida Terhadap Berhubungan Seks SelamaKehamilan dan di peroleh kesimpulan Distribusi frekuensi Pengetahuan Ibu Hamil Primigravida Terhadap Berhubungan Seks Selama Kehamilan Sebagian besar berpengetahuan kurang sebanyak 30 orang $(62,5 \%)$ dari 48 responden.

Distribusi frekuensi Kecemasan Ibu Hamil Primigravida Terhadap Berhubungan Seks Selama Kehamilan Sebagian besar dengan kecemasan kurang baik sebanyak 18 orang (37,5\%).Adanya hubungan yang signifikan antara pengetahuan dengan Kecemasan Ibu Hamil Primigravida Terhadap Berhubungan Seks Selama Kehamilan di Wilayah Kerja Puskesmas Sei Langkai Kota Batam dengan uji chi-square dengan $p<0,05$. Dengan hasil $p$ value $<0,003$ )

\section{KESIMPULAN}

1. Distribusi frekuensi Pengetahuan Ibu Hamil Primigravida Terhadap Berhubungan Seks Selama Kehamilan Sebagian besar berpengetahuan kurang sebanyak 30 orang $(62,5 \%)$ dari 48 responden.

2. Distribusi frekuensi Kecemasan Ibu Hamil Primigravida Terhadap Berhubungan Seks Selama Kehamilan Sebagian besar dengan kecemasan kurang baik sebanyak 18 orang $(37,5 \%)$.

3. Adanya hubungan yang signifikan antara pengetahuan dengan Kecemasan Ibu Hamil Primigravida Terhadap Berhubungan Seks Selama Kehamilan di Wilayah Kerja Puskesmas Sei Langkai Kota Batam Tahun 2020 dengan uji chi-square dengan $p<0,05$. Dengan hasil $p$ value $<0,003$. 


\section{DAFTAR PUSTAKA}

Ana Rahmawati, 2004, Sikap dan Perilaku Seksual pada Ibu Hamil di Poliklinik Kebidanan RS Panembahan Senopati Bantul, Karya Tulis ILmiah, Yogyakarta.

Andik, 2009, Kecemasan Pada Saat Kehamilan

Arikunto, Suharsimi, 2002, Prosedur Penelitian, Cetakan kedua belas, Rineka Cipta, Yogyakarta.

Azwar, S., 2005, Penyusunan Skala Psikologi, Pustaka Pelajar, Yogyakarta.

Chaplin, J. P., Kamus Lengkap Psikologi, Penerjemah: Kartini Kartono, Edisi kesatu, Cetakan kesembilan, Raja Grafindo Persada, Jakarta.

Darrly, 2009 Sex During Pregnancy, 26 Januari 2009.

Ircham Machfoedz, a. 2008, Teknik Membuat Alat Ukur Penelitian, Cetakan keempat, Fitramaya, Yogyakarta., b. 2008, Metodologi Penelitian, Cetakan keempat, Fitramaya, Yogyakarta. c. 2008,

Statistika Deskriptif, Cetakan Keenam, Fitramaya, Yogyakarta.

Kaplan, H., dan Sadock, B.J.2000, Ilmu Kedokteran Jiwa Darurat, Widya Medika, Jakarta.
Kusmiyati, Wahyuningsih dan Sujiyatini, 2009, Perawatan Ibu Hamil, Cetakan ketiga, Fitramaya, Yogyakarta.

Manuaba, I.B.G., 2000, Memahami Kesehatan Reproduksi Wanita, Arcan,Jakarta.

Maramis, 2004, Ilmu Kedokteran Jiwa, Cetakan kedelapan, Air Langga University Press, Surabaya.

Nurcahyati, 2004, Hubungan Tingkat Kecemasan Ibu Hamil dengan Frekuensi Hubungan Seksual pada TM I-III di Puskesmas Ngampilan Yogyakarta, Yogyakarta.

Notoatmodjo, S., a. 2005, Metodologi Penelitian Kesehatan, Rineka Cipta,Jakarta., b. 2003, Pengantar Pendidikan Kesehatan dan Ilmu Perilaku, Renika Cipta,Jakarta.

Prawirohardjo, S., a.2003, Ilmu Kandungan, Yayasan Bina Pustaka,Jakarta. b. 2002, Ilmu Kandungan, Yayasan Bina Pustaka, Jakarta

Solihah,L., 2005, Rahasia Hamil Sehat, Cetakan Pertama, Diva Press, Yogyakarta. 